\title{
The Danish Translation of Amadis de Gaula in the Thott Collection in the Royal Danish Library, Copenhagen
}

\author{
A Novel of Chivalry in Denmark
}

This chapter is concerned with an early modern manuscript, kept in the Thott Collection of the Royal Danish Library in Copenhagen (Ms. Thott 470 8vo), which contains a Danish translation of book I of the famous novel of chivalry Amadis de Gaula.

The following contribution will start with some remarks on the European transmission of the Amadis novel in order to illuminate the international cultural background of the text presented in the Danish manuscript. The first extant edition of Amadis de Gaula was printed in Spain in 1508, and soon it advanced to probably the most popular and most widely disseminated European novel of chivalry in the early modern period. Numerous translations as well as continuations were produced. Its success also reached northern Europe, represented mainly by the Thott manuscript but also by references in other literary works and in various cultural contexts in Scandinavia (e.g. theatre performances at the Swedish royal court in the late eighteenth century).

In the main part of the chapter, some relevant questions concerning the transmission of the text are discussed. Being part of a cross-European tradition, the Danish Amadis translation is regarded as a text in motion, which means that various aspects of textual instability and textual dynamics have to be focused on here. Hence, paratexts also play an important role. The designation in the Danish title as historie 'story/history' refers back to the genre tradition of early modern novels and chapbooks in Denmark (and Sweden), which had been printed continuously since the sixteenth century. Another important aspect is the relationship between the manuscript, its dissemination and reception, to the early novel in Scandinavia, especially to the Danish novel Den beklædte sandhed (1723), consistently regarded in Danish literary history as the first Scandinavian novel. It is also significant that the Danish Amadis manuscript, Thott 470 8vo (which can cautiously be dated to the time around 1700), was produced within a relatively well-established print culture. As proved by the bibliographical data, no printed copy of the Danish Amadís translation seems to exist. Therefore, interactions between manuscript culture and print culture also appear of great interest in this context.

Anna Katharina Richter, University of Zürich

Ә Open Access. ( 2021 Anna Katharina Richter, published by De Gruyter. (c) BY-NC-ND This work is licensed under the Creative Commons Attribution-NonCommercial-NoDerivatives 4.0 International License.

https://doi.org/10.1515/9783110695366-008 
The present chapter is part of a larger study of the Danish manuscript Thott 470 $8 \mathrm{vo}$ and the reception of the Amadís novel in Scandinavia. The following presentation, therefore, is intended as a kind of prelude to this investigation.

\section{The European dimensions of the story}

The earliest extant edition of Amadís de Gaula consists of four books and was printed in Zaragoza, Spain, in 1508 by Jorge Coci's printing house as Los quatro libros del virtuoso cavallero Amadís de Gaula. ${ }^{1}$ Garci Rodríguez de Montalvo (c. 1440-c. 1503) is named as the author or corrector, and also announces a book V, which was printed in Seville in 1510 under the title Las sergas de Esplendian, hijo de Amadís de Gaula (Norton 1978: 296). Amadís has a long and complex history of both manuscript and print transmission; the earliest references to a text called Amadis are Castilian and date from the fourteenth century (Weddige 1975: 1-11; Schaffert 2015: 1-22). ${ }^{2}$ The chivalric and love narrative about Prince Amadís and his many adventures is inspired by the French Arthurian romances, which came to Spanish and Portuguese courts from the end of the twelfth to the beginning of the fourteenth century. In a second stage, they were adapted and translated, and finally, they served as inspiration for the creation of new chivalric novels like Amadís (Weddige 1975: 2).

A very short summary of the complex plot structure of Amadis de Gaula could be the following. Amadís is the son of the secret love between Perion, king of Gaul (Wales), and Princess Elisena. As an infant, he is carried out to sea and brought to Scotland, and later on, as a young man, even to the court of the king of Scotland. There he meets Oriana, the daughter of Lisuarte, king of Great Britain, and falls in love with her. In various adventures and encounters, Amadís proves himself a marvellous knight, also together with his brother Galaor (in the meantime, Perion has married Elisena and had another son with her, Galaor, who is now grown-up). Amadís and Galaor manage to help Lisuarte, who has been deprived of his kingdom and, together with Oriana, been taken prisoner by the wizard Arcalaus. Amadís manages to rescue Oriana, and they have a son together, Esplandian, who is the hero of the later part of the story and also of its continuations. The series of adventures and combats Amadís has to experience in different parts of Europe as well as

1 It seems to be a general consensus that the editio princeps was produced in 1496, but the earliest extant version is the 1508 print. Cf. Thomas (1920: 41-42). For details on the 1508 print, cf. Thomas (1920: 63) and Norton (1978: 178, 231-232, 296, 350, 365). Cf. also Cacho Blecua (2008: 128-162).

2 The Castilian fragments of a medieval Amadís romance were found in 1955 and have been published by Lucía Megías (2008: 80-94). 
in fictive places continues in the following books II, III, and IV. Finally, Amadís and Oriana, who appear as the epitome of a knight and his lady, are united again. ${ }^{3}$

The Spanish romance developed very soon into what one might call an early modern bestseller and a very successful novel series: as early as 1510 (i.e. when Montalvo's book V was printed), the first continuation of the Amadís novel, written by another author, Ruy Páez de Ribera, was printed in Salamanca, followed by further continuations (books VII-XII) by three different Spanish authors (Weddige 1975: 10-15; Thomas 1920: 41-83). ${ }^{4}$ Shortly afterwards, the international career of Amadís de Gaula began. First, the Spanish books I-V were translated from Spanish into French by Nicolas de Herberay Des Essarts, and printed in Paris, between 1540 and 1544, then books VII and IX (which became the French books VI, VII, and VIII, also translated by Des Essarts and published 1545-1548), followed by further French translations and continuations until 1615 (Weddige 1975: 22-28). Italy was a successful market, too; in the period 1546-1551, the Venetian publisher and book dealer Michele Tramezzino published ten of the twelve already-existing Spanish Amadís books in Venice, translated into Italian by Mambrino Roseo da Fabriano, and followed by new continuations and diverse supplementa (Weddige 1975: 16-21). Between 1540 and 1615, the French Amadís books grew into the famous Amadís series consisting of no less than twenty-four books, involving nine translators and around thirty printers and publishers - and with a very complex transmission (Weddige 1975: 26).

In Germany, Amadís first appeared in 1569 with German translations from the French editions, printed by Sigmund Feyerabend's printing house in Frankfurt; the last editio princeps (of book XXIV) was published in 1595, the last reprint of an Amadís book in 1617 (Weddige 1975: 29-95). The enormous success of the Amadís series also reached the Netherlands and England; even a Hebrew translation of book I, dating from 1534-1547, is extant (Thomas 1920: 59-63; Weddige 1975: 97-113). ${ }^{5}$

In actual fact, the novel series had a Europe-wide success and a long afterlife until the end of the eighteenth century - not only in translations, continuations, and critical-theoretical discussions about fictional literature and the novel in general, for it was also transformed into operas composed by Jean Baptiste Lully (Amadis, 1684), Georg Friedrich Händel (Amadigi, 1715), and others. ${ }^{6}$ Above all, Amadís

3 For this brief summary, cf. Thomas (1920: 41-47).

4 For the early Amadís editions, cf. Norton (1978: 178 (Amadís book VI), 296 (book V), 350 (book VII)). 5 Cf. also the overviews by Neri (2008: 565-591), Schaffert (2015: 9-22), and Bologno et al. (2013, esp. the tabular overview of the European diffusion of Amadis by Stefano Neri (196-197)). Buzon (2018) discusses the various translations of Amadís.

6 Other adaptations for the opera stage were, for example, the three opere serie Amadis de Grèce (Paris, 1699) by André Cardinal Destouches and Antoine Houdar de La Motte, Oriana (Hamburg, 1717) by Reinhard Keiser and Joachim Beccau, and Amadis aus Griechenland (Munich, 1724) by Pietro Torri and Sebastiano Biancardi. German opere buffe and Singspiele based on Amadís were also composed, corresponding to the literary Amadís parodies. Cf. Weddige (1975: 296-308). 
plays an important role in the history of literary fiction as a starting point for many adaptations, parodies, or free renderings - from Bernardo Tasso's Italian verse adaption Amadigi de Gaula (1560) until the end of the eighteenth century, for example Christoph Martin Wieland's Der Neue Amadis (1774) (Weddige 1975: 309-314). The most famous text among them, is, of course, Miguel Cervantes's Don Quijote (1605/1615), often regarded as the first European novel. The emergence of a Don Quijote would probably never have been possible without Amadís.

\section{The Thott Collection manuscript}

In early modern Sweden and Denmark, the Amadís novel was obviously read and well known (probably in German editions) by members of the educated upper class and the nobility, as can be seen from various literary references dating from the seventeenth and early eighteenth centuries (Richter \& Glauser 2018: 33-34). ${ }^{7}$

7 One important example is the private library of the Swedish nobleman and politician Hogenskild Bielke (1538-1605), "one of the greatest collectors of printed books and legal manuscripts in Sweden of his generation" (Hogenskild Bielke's Library: 9), who owned six volumes of German Amadís prints in his famous book collection. Further indication of the knowledge of Amadís is provided in the seventeenth-century Swedish translations of a moral-didactic work by Aegidius Albertinus (1560-1620), a German Catholic writer and translator in the age of the Counter-Reformation. His Weiblicher Lustgarten (itself a translation of the Latin work Hortulus muliebris quadripartitus by the Spanish author and Jesuit Juan de la Cerda, 1560-1643) was first printed in Munich in 1605 (editio princeps). The Swedish translation performed by the Royal Translator Ericus Schroderus was printed in Stockholm in 1638; later editions were published in Gothenburg in 1645 and 1675. I have used only the 1675 edition of Agidii Albertini Hortulus muliebris (which has been digitized) in this article. Cf. also Collijn (1942: 8-9). Amadís is mentioned in the first part (which deals with the education of girls and young women) of the latter work, in chapter 2, where young ladies are warned against the reading of secular books, which are depicted as "false and untruthful books", because they seduce their (female) readers to moral debasement: Och på thet alt Tilfälle til onda Tanckar och Kättja må them affstäckt warda / skal man affhända them / och aldeles vthur theras Ögon affskaffa the Böcker / som äre skrefne om Ridderskap och fåfäng Älskogh / såsom äre Amadís de Gaula, H. Tristrant och andra slijka skamlösa Böcker. Ty huru är thet möijeligit / at then kleena Kyskheeten kan wara säker / emellan then snöda och fäfänga Kärleekens Wapn / hwar medh slijka Prophaniske / oährlige / falske och förlugne Böcker äre vpfylte (Egidii Albertini Hortulus muliebris: fol. C2v (p. 26)). 'And in order to extinguish every opportunity for bad thoughts and voluptuousness for them [i.e. young women], you should take away and remove those books from their eyes that deal with chivalry and vain love, such as Amadís de Gaula, Sir Tristant, and other impudent books. Because how would it be possible for weak chastity to be safe, facing the weapons of vile and vain love, which these secular, dishonest, false, and untruthful books are filled up with' (all English translations are my own if not indicated otherwise). This view is the typical argument against the reading of Amadís and the reading of romances in general; cf. e.g. Weddige (1975: 181-291) on the discussion and criticism of Amadís. 
Regarding the novel's extensive circulation in Germany and its Europe-wide success, it is not very surprising that it was well known in Denmark and was even translated into Danish. It is rather remarkable, however, that the Danish translation of book I of Amadis de Gaula, which actually exists in manuscript form (Ms. Thott $4708 \mathrm{vo}$ in the Thott Collection of the Royal Danish Library in Copenhagen), seems to date to have been neglected by researchers in early modern Scandinavian literature (cf. Richter \& Glauser 2018). Since 1785, when the huge private book and manuscript collection of Count Otto Thott (1703-1785), minister of state and book collector, was acquired, the manuscript has been owned by the Royal Danish Library. Although already recorded in 1795 in the Index codicum manuscriptorum, the Bibliotheca Thottiana's printed catalogue of manuscripts belonging to the Thott Collection, ${ }^{8}$ its existence still seems to be unknown to Danish (and Scandinavian) literary scholars. ${ }^{9}$ The international Amadís scholarship does not mention any Scandinavian translation of the novel either. ${ }^{10}$ It is therefore about time to bring this line of the transmission of the work into scholarly discussion.

The manuscript Thott 470 8vo is a paper manuscript in octavo format. It has a book cover and contains a good six hundred unpaginated pages, starting directly

8 In the Index codicum manuscriptorum (1795: 529), the Amadís manuscript is listed as no. 470: Historien om Amadis af Frankerige, udsat af Tydsk (The history of Amadis of France, translated from German). In the Index, it is recorded in the section on Danish, Norwegian, and northern German history ("Danica, Norvegica, Slesvico-Holsatica"; cf. Index: 529).

9 Paulli comments on "Folkebøgernes Historie" (History of the Danish chapbooks) in Jacobsen, Olrik and Paulli (1936: 230): "Amadis-Romanerne, som allerede i Slutningen af det 16. Aarhundrede fortrænger Folkebøgerne i den tyske Overklassens Gunst, bliver slet ikke oversat hos os [. . .]" (The Amadis novels, which had already displaced the chapbooks in the favour of the German upper class in the late sixteenth century, were not translated here [i.e. in Denmark] at all). The main Danish literary histories do not mention any Danish translation of Amadís either: cf. e.g. Petersen (1867); Petersen and Andersen (1924-1934); Friis (1975); Dansk Litteraturhistorie (1983-1985); Jørgensen and Wentzel (2005); Mai (2010). Stangerup (1936: 22-23) mentions that “[f]ørbarokkens Romantyper: Amadisromanen og Hyrderomanen maa siges at være saa temmelig forsvundet i Danmark efter Aar 1700. At de har været kendt tidligere, fremgaar af Auktionskatalogerne, der endnu annoncerer 'Livre de Amadis' et Par Gange og har et temmeligt stort Udvalg af Hyrderomaner [. . .]" (it might be said that models of the pre-baroque novel, i.e. the Amadis novel and the pastoral novel, almost disappeared in Denmark after 1700. But it is evident from catalogues of book auctions, which still announce 'Livre de Amadis' several times and which present quite a big selection of pastoral novels [. . .], that they had previously been known). A commentary in an 1843 edition of the Danish writer Ludvig Holberg's comedies states directly that there is no Danish translation of the Amadis novel at all (Ludvig Holbergs Comedier (1843: 309)): "Den franske Ridder-Roman fra Middelalderen: Amadis de Gaule, er derimod aldrig oversat paa Dansk" (The French chivalric romance from the Middle Ages, Amadis de Gaula, however, was never translated into Danish).

10 Cf. the discussion of the French, Italian, Spanish, Dutch, and English versions in Weddinge (1975: 107-111); Amadis de Gaula 1508 (2008); Schaffert (2015); Bologno et al. (2013); Lucía Megías and Marín Pina (2008). 
with the Amadis story on the first page, without a separate title page (cf. Figure 1). There are no other texts apart from Amadís in the manuscript. No translator or owner of the manuscript is named, and there is neither a dedication nor a preface. The headline presents the following text as a translation from the German:

Historie / om Amadis af Franckrige, meget Lystig og Kortwillig for unge Mennisker at læße med hoß følgende goede Lærdommer paa vores dans[ke] sprog, af tydsken udsatt.

(Thott 470 8vo, [pag. 1])

History of Amadis from France, very pleasant and diverting to read for young people, with good advice attached, in our Danish language, translated from German.

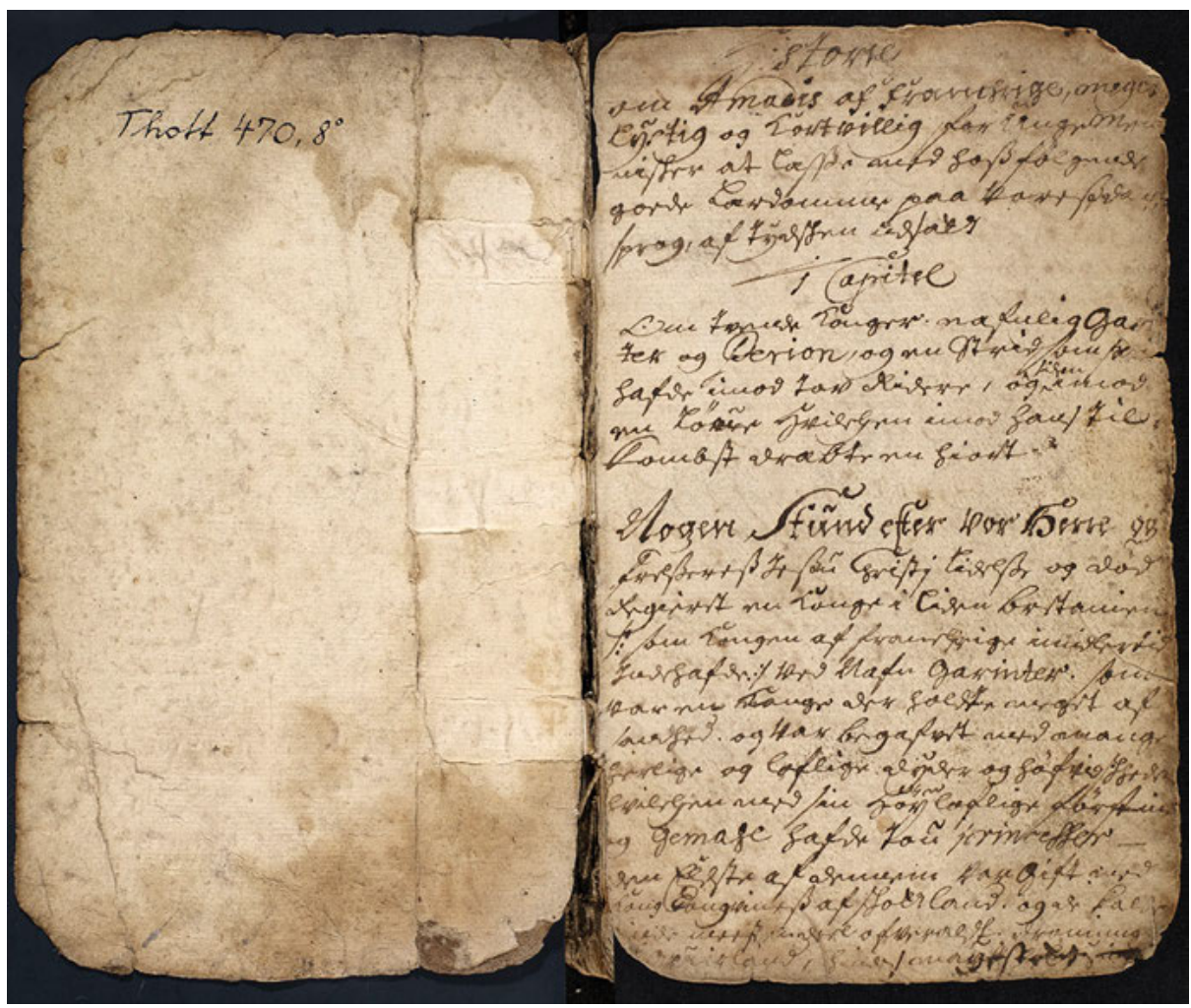

Figure 1: Manuscript Thott 470 8vo, [pag. 1]. (C) The Royal Library Copenhagen. Photo: Photographic Studio, The Royal Library Copenhagen.

This Danish Amadís contains forty-four chapters, which correspond to the German tradition, as does the order and the numbering of chapters in book I. It also takes over the brief summaries of each chapter from the German prints and thus follows 
the tradition of the first German edition. ${ }^{11}$ The text seems to be written by a single hand, dating approximately from the last part of the seventeenth or the very beginning of the eighteenth century. ${ }^{12}$ The manuscript on the whole is in a very neat script, with only a few corrections (if any) on each page. Might it have served as a printer's setting copy? As there are no Danish Amadís prints registered in the Bibliotheca Danica (1961-1963 [1877-1914]), it seems that, according to the bibliographical data, the Danish translation remained in manuscript status and never went into print.

Another idea might be that the manuscript was produced just for a limited literary circle in Denmark (in Copenhagen?) and was never actually intended to go into print at all. ${ }^{13}$ My current research project, which includes an annotated edition of the Danish Amadis manuscript, Thott 470 8vo, with a commentary on its literary and book-historical context, will hopefully shed some light on the circumstances surrounding the creation of this Danish Amadis translation. Probably the most fascinating aspect, however, is what we could describe as the dynamics of Amadís de Gaula and its international transmission - including the case of Thott $4708 \mathrm{vo}$ and its importance as a manuscript documentary in a predominantly printed culture. Moreover, the manuscript is a fascinating document in the history of (translated) prose literature in early modern Scandinavia. ${ }^{14}$

\section{The Danish Amadis as a text in motion}

As a text circulating in so many European language areas throughout the sixteenth, seventeenth, and eighteenth centuries, and with roots in the medieval Arthurian tradition, Amadis is a highly relevant object for a larger study focusing on the transmission, the movement, and the instability of (early modern) texts. The following

11 This is evident if we compare the Danish manuscript to the German first edition (Newe Historia [. . .]; Frankfurt, 1569). The second German Amadís edition was published in 1571, again by Feyerabend's printing house in Frankfurt. It is not clear yet exactly which copy of the first edition was used as source text by the Danish translator. But it seems to be obvious that the German text served as a model for the translation. In my project, the relations to the German tradition will be analysed in more detail.

12 Cf. Kroman (1943: 54-55). This is a first assessment based on the style and writing design of the manuscript, but of course this needs to be further investigated.

13 I would like to thank my colleague Simon Skovgaard Boeck, Copenhagen, who proposed considering this aspect at the "Modes of Modification Kick-Off-Conference" in Oslo, 29-30 November 2018.

14 My work on Ms. Thott $4708 \mathrm{vo}$ is part of a larger research project on prose literature in late premodern Scandinavia, supported by the Swiss National Science Foundation (SNF). The project started in February 2020 at the Scandinavian Department at the University of Zurich, and is led by Klaus MüllerWille and Lena Rohrbach: "Romanhaftwerden. Skandinavische Prosaliteratur der späten Vormoderne” https://www.ds.uzh.ch/de/projekte/romanhaftwerden.html (15 June 2020). 
considerations, therefore, will discuss some aspects concerning the Danish Amadís as an example of a dynamic text - a text in motion. ${ }^{15}$

The idea of mouvance, as described by Paul Zumthor for medieval literature (cf. e.g. Zumthor 1972; 1987) and further developed by Bernard Cerquiglini in his concept of variance as the main criterion for medieval writing (cf. Cerquiglini 1989), is also applicable to premodern texts. Even premodern texts are (still) marked by textual instability and by a textual dynamic that was not automatically replaced by textual stability when book printing was established, as pointed out by Jürg Glauser:

Während sich zur Beschreibung der mittelalterlichen Manuskriptkultur und ihrer umfassen-
den handschriftlichen Kopiertätigkeit der Begriff der Varianz inzwischen allgemein durchge-
setzt hat und diese geradezu als eine der Voraussetzungen der Text- und Schriftkultur des
Mittelalters verstanden wird, zeigt sich bei genauerer Betrachtung, dass das Oszillieren zwi-
schen Textkonstanz und Textvarianz keineswegs an die Handschriftlichkeit gebunden ist. Viel-
mehr definieren Unfestigkeitsphänomene auch den frühen Buchdruck, so dass zumindest in
Bezug auf die Aspekte der Textualität spätmittelalterlicher und frühneuzeitlicher Erzählungen
keineswegs von einer durch den Medienwechsel bedingten Ablösung von Varianz durch Stabi-
lität gesprochen werden kann.
(Glauser \& Richter 2011: 1)

We can identify two aspects, interconnected with each other, where the Danish Amadis manuscript in the Thott Collection and the question of textual dynamics and variance are concerned. Regarding the discussion of the (early modern) novel in Scandinavia, the rhetoric of the paratext plays a significant role. This could be described as a first aspect of dynamics and variance. The second aspect then touches on the literary context in Denmark around 1700.

\section{"Historie": what the paratext tells us}

The Danish manuscript in the Thott Collection has no separate title page, but the heading says, as already mentioned above: Historie / om Amadis af Franckrige, meget Lystig og Kortwillig [. . .] at læße (History of Amadis from France, very pleasant and diverting to read [. . .]). Defining itself as a "historie", the text ties in especially with the poetics of the "pleasant histories", that is, the early modern novel and chapbook tradition in Scandinavia (cf. e.g. Richter 2009; Wingård 2011; Glauser 2016). These texts are mostly referred to as "folkebøger" and "folkböcker" in Danish and Swedish literary history respectively (for surveys, cf. e.g. Richter 2009; Wingård 2011). The intended close relation to historiography and its inherent objective truth that is established by the use of "historie" in the title of early modern prose narratives has

15 The present chapter can only give an outline of some of the main aspects my research project will deal with. 
been discussed extensively for the German and, partly, the Scandinavian traditions (cf. e.g. Müller 1985; Braun 2004; Richter 2009).

Since the very first edition in 1569, German Amadís editions use Historie in their title. With its reference to "historie", however, the Danish title of the Amadis manuscript can be seen not only as a translation and a tradition taken over from the source text. This title is also a reference to a specific literary tradition: the tradition of the "folkebøger" ('chapbooks') or early modern novels in Scandinavia. It is quite possible that it is this particular literary background that the Danish Amadis translator wanted to refer to and wanted the text to be received and placed in, as many of these early modern novels were still reprinted, read, and well known in eighteenth-century Scandinavia (cf. e.g. Richter 2009: 33-139). The likely dating of the manuscript was also the time when the (modern) Scandinavian novel emerged: Den beklædte Sandhed by Anna Margrethe Lasson was published in 1723 in Denmark as the first Scandinavian novel (cf. Mai 2011), and Jacob Mörk and Anders Törngren in Sweden wrote what is considered the first Swedish novel, Adalriks och Giöthildas Äfwentyr (1742-1744) (Malm 2001).

Early novels and “folkebøger”, like Amadís, were disseminated across large parts of Europe and translated into numerous vernacular languages, and thus adapted to varying cultural and social (and sometimes also religious) contexts - Melusine, Magelone, Griseldis, Flores and Blancheflor, Octavian, Reynicke Vosz (Reynard the Fox), Ulenspiegel, Doctor Faustus, and so on. Many of these early novels were reprinted again and again from the sixteenth until the late nineteenth century (cf. e.g. Richter 2009: 7-22). ${ }^{16}$ Unquestionably, we can regard them as texts with a great Zeittiefe (cf. Tristram 1994), that is, a complex transmission in time and space, and thus as highly relevant for studies in textual transmission. Various modes of modification and variance can be observed in these texts during their transmission, concerning textual and medial changes, as well as omissions in the narratives and various forms of changes in title pages and illustrations (cf. e.g. Richter 2009; Wingård 2011). Even if Amadis neither shows the same process of such a complex reception in Scandinavia until the nineteenth century, nor reached the same popularity as the "folkebøger" did, we can nonetheless say that it holds a special position in the history of the early novel in Scandinavia. Amadís is - like the "folkebøger" - part of the tradition of translating and adapting continental European narratives to the Scandinavian literary cosmos, and it was produced at a time when different modes of experiencing the early modern novel were circulating in Scandinavian literature.

16 Many of the titles (Danish first editions) are recorded in the Universal Short Title Catalogue (USTC): https://www.ustc.ac.uk/ (15 June 2020). 


\section{The Danish Amadis and the early Danish novel}

The Danish Amadís manuscript in the Thott Collection could be seen as an interesting example of the dynamic process of translating and adapting a very famous "old text" for a "new" context in Denmark around 1700. It is striking that the phase of the greatest popularity of Amadís in continental Europe had long passed when the Danish manuscript was probably produced (cf. Weddige 1975: 110-113). We can assume that the Danish readership of the manuscript was literate and learned, maybe even multilingual, and thus familiar with the long European Amadís tradition. It is also remarkable that the first Danish and Nordic novel, Anna Margrethe Lasson's Den beklædte sandhed (published 1723, but complete in manuscript form already in 1715) "takes as its models seventeenth-century pastoral romances and heroic-galant novels” (Mai 2011).

It is a well-known fact that European, especially French and German, sixteenthand seventeenth-century literature was well known and read in early modern Scandinavia: Søren Terkelsen's Danish translation of the first part of Honoré d'Urfé's famous novel Astrée (1645/1646), and especially his setting to music of the songs in Astrée as well as his translations of baroque love songs by Johann Rist and Gabriel Voigländer in the collection entitled Astree Siunge-Choer from $1648-1654,{ }^{17}$ or Urban Hiärne's pastoral novel Stratonice from $1666 / 1668,{ }^{18}$ are only two famous examples of the reception of continental baroque texts in Scandinavian literature, each reflecting the influence and the aesthetics of the early modern (French) novel.

Of course, it would be thrilling if we could figure out the possible translator of the German Amadís book I into Danish, or at least track down a closer circle of scholars and/or authors who could have been involved in the translation. But even if we do not (yet) know the circumstances of the production of the Thott manuscript in detail, it is of great interest to examine the extent to which the Danish Amadis translation can be set in the context of the emergence of the novel in Denmark. It is quite possible that the Amadis tradition could have served (in part) as inspiration for the sujet and the style of Anna Margrethe Lasson's novel, a matter that will hopefully be discussed in more detail in my study. Amadís still seems to have been both present and prominent as an intertextual reference in the writings of influential Danish authors in the eighteenth century, as there are references to Amadís by Ludvig Holberg in the fictional preface to Peder Paars (1720) and in his comedy Den Vægelsindede (1731). ${ }^{19}$ Later on in the eighteenth century, Johannes Ewald also

17 Cf. the chapter on Søren Terkelsen in vol. 1 of Dansk litteraturs historie (2007: 346-350).

18 Hiärne's novel remained in manuscript form and was published in 1952 by Magnus von Platen (cf. Hiärne 1995: 7).

19 Cf. Ludvig Holbergs Skrifter 2009-. www.holbergsskrifter.dk (15 June 2020). 
refers to the novel and its hero in his autobiographical Levnet og Meeninger (letters written 1774-1778). ${ }^{20}$

The textual dynamic of the Danish Amadís can be seen on the one hand in its literary background in the long and rich narrative tradition of the original Spanish novel, with its translations and adaptations into different European languages, and the textual variations that can be found in this broad transmission. On the other hand, the possible impact on early Danish novels like Lasson's Den beklædte sandhed (genre, plot, style, and so on), and the position of the Danish Amadis manuscript in the aesthetic and poetological discussion of the novel in general in the first part of the eighteenth century in Scandinavia, actually creates a textual dynamic of its own. As pointed out by Sif Rikhardsdottir,

[t] he history of European literature is one of transformation, refashioning and intertextual relations. Narrative modes and ideas spread across the continent, influencing and enriching existing native literary forms. As old poetic traditions either stagnated or died out, new literary modes were fashioned from pre-existing forms, which were combined with novel narrative structures and ideas from imported materials. The foreign literary conventions did not replace existing forms, but rather served as the impetus for the enrichment of the native literary language and of its poetic and thematic representation.

(Sif Rikhardsdottir 2012: 1)

This statement is extremely relevant for any analysis of the Danish Amadís manuscript, as this document is part of the rich and various European (though primarily printed) Amadis tradition and contains a famous example of the "imported materials”, as Sif Rikhardsdottir puts it, that enriched the Danish native literary language. Regarding the references in contemporary Scandinavian literature, but also the enriching influence on both literary texts and other cultural representations, the reception of Amadís created a certain textual and cultural dynamic. At this point, the connections, or rather parallels, to the Scandinavian transmission of the "folkebøger" and early modern novels can be seen once again. Even these texts are rooted in European and international narrative modes from the ancient, the medieval, and the Renaissance traditions. By being translated into Danish and Swedish (and Icelandic), ${ }^{21}$ and thus "imported" into Scandinavia, they went through a complex process of adaptation to a new readership in a new culture - and enriched the native literary languages in the Nordic countries. There should also be little doubt that the Danish Amadis can be regarded as a part of the intertextual relations between Nordic and

20 "Jeg kunde, om det havde behaget Himmelen, gjerne have blevet en Aesopus, eller en Diogenes, gjerne en Hercules eller en Amadis, selv en Zopyrus, en Scævola og en Curtius - Men en Aristoteles eller en Scotus, en du Guesclin eller en Cartouche, en Colbert eller en Sejan - det var mig platud umueligt at blive - [. . .]" (Ewald 1988: 93-94). (If Heaven had wished it, I also could have become an Aesop or a Diogenes, a Hercules or an Amadis, even a Zopyrus, a Scævola, and a Curtius - but an Aristotle or a Scotus, a du Guesclin or a Cartouche, a Colbert or a Sejan: this was just impossible for me to become - [. . . ]).

21 For the Icelandic "folkebøger”, cf. the fundamental study by Seelow (1989). 
continental literature described by Sif Rikhardsdottir in the quotation above, and hence as a part of a dynamic European textual network.

\section{Conclusion}

This chapter has provided a first insight into the manuscript Thott 470 8vo, probably dating from $c .1700$ and containing a Danish translation of book I of the novel of chivalry Amadís de Gaula, a document which has to date been considered neither by international Amadís research nor in Scandinavian literary historiography. A brief illumination of the complex European history of the transmission, translation, and reception of the Amadis novel has shown how widespread and present (in literature as well as in other cultural manifestations) this text was over a long period of time and in many parts of Europe. Aspects of transmission, variance, Zeittiefe, and textual dynamics have been related to this text, allowing us to observe some parallels with the tradition of the early modern novels and "folkebøger". My future study, therefore, will focus on the context and the literary environment of the Thott manuscript, relating it to the emergence of the early novel in Denmark, for example Anna Margrethe Lasson's Den beklædte sandhed (1723). As one of the "imported materials" transferred from the continent to Scandinavia, as described by Sif Rikhardsdottir, the Thott manuscript will also be examined with regard to the relationships between the Danish translation and its source text, and to possible cases of variance that are unique to the Danish translation. The aim of the study is to analyse the manuscript in a wider context, considering among other aspects the reception of the Amadis novel in Denmark (and Scandinavia) in the early modern era, its impact on the history of literary translation, and its status in the discussion about the novel as a (new) literary genre in Denmark in the time around 1700, when Thott $4708 \mathrm{vo}$ was probably produced.

Last but not least, the Thott manuscript is also a fine example of the representation of manuscript culture and manuscript transmission in a culture dominated by printing and the printed book. It is remarkable that at the time when the Danish translation was probably produced, a six-hundred-page manuscript was circulating and (probably also) read and studied by an audience still interested in the famous Renaissance romance of chivalry of Amadis de Gaula and his adventures, which had already been disseminated in print all over Europe in numerous languages and various editions for almost a century, and had a rich afterlife in literature and music even as far as the end of the eighteenth century. The Danish manuscript is thus understood as part of this European history of transmission and as part of the rich literary exchange between Scandinavia and the continent. 


\section{Bibliography}

\section{Printed Sources}

AEgidii Albertini Hortulus muliebris qvadripartitus, thet är: Thet Qwinlighe Könetz Lust-Gård / Vthi fyra åthskillighe deelar afdeelt / hwar vthi förhandlas: I. Om Barne-Tuchtan och JungfrwStåndet. II. Om ächta Qwinnors Stånd. III. Om Enckio-Ståndet. IV. Om Qwinkönetz goda och onda Egenskaper i gemeen. Allt medh sköne både andlige och werdzlige Historier och Exempel amplificerat och förklarat. / Vthtolkat aff Erico Schrodero. / Götheborg / Tryckt hoos Amund Grefwe / Åhr 1675. (Umeå Universitetsbibliotek: 900656 , digitized by Umeå University Library: http://digibook.ub.umu.se/eod/20111096.pdf (1 October 2020).

Ewald, Johannes. Herr Panthakaks Historie. Levnet og Meeninger. Tekstudgivelse, efterskrift og noter af Johnny Kondrup. Danske Klassikere. København: Det danske Sprog- og Litteraturselskab, 1988.

Historie / om Amadis af Franckrige. Manuscript in Det Kongelige Bibliotek København, sign. Thott 4708 vo.

Ludvig Holbergs Comedier. Udgivne med Anmærkninger under Texten, Indledninger og Oplysninger til ethvert Lystspil, for det Holbergske Samfund.Vol. 1. Kiøbenhavn, 1843.

Ludvig Holbergs Skrifter, ed. Karen Skovgaard-Petersen, et al. Københav: Det Danske Sprog- og Litteraturselskab, 2009-. www.holbergsskrifter.dk (15 June 2020).

Newe Historia/Vom Amadis auß Franckreich/ seer lieblich vnd kurtzweilig / auch den junge[n] nützlich zulesen / mit viel angehefften guten Leeren / newlich auß Französischer / in vnser algemeine / geliebte Teutsche sprach gebracht. Gedruck zu Franckf. 1569. (durch Peter Schmidt / in verlegung Hieronymi Feyrabends). (VD 16 A 2113, digitized by Österreichische Nationalbibliothek Wien: http://data.onb.ac.at/ABO/\%2BZ181254106 (1 October 2020)).

Hiärne, Urban. Samlade dikter. Utgivna av Bernt Olsson och Barbro Nilsson. Svenska Vitterhetssamfundet. Svenska författare. Ny serie. Stockholm: Svenska Vitterhetssamfundet, 1995.

\section{Internet sources}

Universal Short Title Catalogue (USTC): https://www.ustc.ac.uk/ (15 June 2020)

On Margrethe Lasson: https://nordicwomensliterature.net/writers/lasson-anna-margrethe/

(8 April 2020)

\section{Literature}

Amadís de Gaula 1508. Quinientos años de libros de caballerías. Biblioteca Nacional de España/ Sociedad Estatal de Conmemoraciones Culturales (Exhibition Catalogue), 2008.

Bibliotheca Danica. Systematisk fortegnelse over den danske litteratur fra 1482-1830, efter samlingerne i Det store kongelige Bibliothek i Kjøbenhavn: Med supplementer fra Universitetsbibliotheket $i$ Kjøbenhavn og Karen Brahes Bibliothek i Odense, ed. Chr. V. Bruun (vol. V by Lauritz Nielsen). Genudg. med tillæg og henvisninger af Det kongelige Bibliotek. Vol. I-V. København, 1961-1963 [1877-1914]. 
Bologno, Anna, et al., eds. 2013. Repertorio delle continuazioni italiane ai romanzi cavallereschi spagnoli Ciclo di Amadis di Gaula. Roma: Bulzoni Editore.

Braun, Manuel. 2004. "Historie und Historien.” In: Die Literatur im Übergang vom Mittelalter zur Neuzeit, ed. Werner Röcke \& Marina Münkler, 317-361. München: Hanser.

Buzon, Christine de. 2018. "Notes sur la circulation d'Amadis de Gaule en Europe de l'ouest: Gabriel Chappuys, traducteur lui-même traduit." Association d'études sur la Renaissance, l'Humanisme et la Réforme (2; no 87): 199-232.

Cacho Blecua, Juan Manuel. 2008. "Los cuatro libros de Amadís de Gaula de Garci Rodríguez de Montalvo." In: Amadís de Gaula 1508. Quinientos años de libros de caballerías. Biblioteca Nacional de España/Sociedad Estatal de Conmemoraciones Culturales (Exhibition Catalogue): 128-162.

Cerquiglini, Bernard. 1989. Éloge de la variante: historie critique de la philologie. Paris: Seuil. [English translation: In Praise of the Variant: A Critical History of Philology, trans. Betsy Wing, Baltimore: Johns Hopkins University Press, 1999]

Collijn, Isaak. 1942. Sveriges bibliografi 1600-talet. Bidrag till en bibliografisk förteckning. Uppsala: Svenska litteratursällskapet.

Dansk Litteraturhistorie. 1983-1985, ed. Peter Holst, et al. København: Gyldendal.

Dansk litteraturs historie. 2007. Vol. 1: 1100-1800, ed. Klaus P. Mortensen \& May Schack. København: Gyldendal.

Friis, Oluf. 1975. Den danske litteraturs historie: fra oldtiden indtil renæssancen. København: Gad.

Glauser, Jürg, ed. 2016. Skandinavische Literaturgeschichte. 2. erw. und aktual. Aufl. Stuttgart/ Weimar: J.B. Metzler.

Glauser, Jürg \& Anna Katharina Richter, eds. 2011. Text - Reihe - Transmission. Unfestigkeit als Phänomen skandinavischer Erzählprosa 1500-1800. Tübingen/Basel: Francke.

Hogenskild Bielke's Library. A Catalogue of the Famous 16th century Swedish Private Collection. 1995. Reconstructed and compiled by Wolfgang Undorf. Uppsala: Uppsala University Library. Index codicum manuscriptorum. 1795. In: Catalogi Bibliothecae Thottianae, tom. 7. København. Jacobsen, Jens P. \& Jørgen Olrik \& Richard Paulli, eds. 1936. Danske Folkebøger fra 16. og 17. Aarhundrede, (vol. 13, ed. by Richard Paulli). København: Gyldendal.

Jørgensen, Jens Anker \& Knud Wentzel, eds. 2005. Hovedsporet. Dansk Litteraturs historie. København: Gyldendal.

Kroman, Erik. 1943. Skriftens historie i Danmark. Fra reformationstiden til nutiden. København: Dansk historisk Fællesråd.

Lucía Megías, José Manuel. 2008. "Apéndice. Edición de los fragmentos conservados del Amadís de Gaula medieval. The Bancroft Library. University of California, Berkeely, UCB 115." In: Amadís de Gaula 1508. Quinientos años de libros de caballerías. Biblioteca Nacional de España/Sociedad Estatal de Conmemoraciones Culturales (Exhibition Catalogue): 80-94.

Lucía Megías, José Manuel \& Maria Carmen Marín Pina, eds. 2008. Amadís de Gaula: Quinientos años después. Estudios en homenaje a Juan Manuel Cacho Blecua. Alcala de Henares: Centro de Estudios Cervantinos.

Mai, Anne-Marie. 2011. "A Passionate Lover of the Danish language." In: The History of Nordic Women's Literature (online). https://nordicwomensliterature.net/2011/08/15/a-passionatelover-of-the-danish-language/ (15 June 2020).

Mai, Anne-Marie, ed. 2010. Hvor litteraturen finder sted. København: Gyldendal.

Malm, Mats. 2001. Textens auktoritet. De första svenska romanernas villkor. Stockholm: Symposion.

Müller, Jan-Dirk. 1985. "Volksbuch/Prosaroman im 15./16. Jahrhundert. Perspektiven der Forschung." Internationales Archiv für Sozialgeschichte der deutschen Literatur (1. Sonderheft Forschungsreferate): 1-128. 
Neri, Stefano. 2008. "Cuadro de la difusión europea del ciclo del Amadís de Gaula (siglos XVI-XVII).” In: Amadís de Gaula: Quinientos años después. Estudios en homenaje a Juan Manuel Cacho Blecua, ed. José Manuel Lucía Megías \& Maria Carmen Marín Pina, 565-591. Alcala de Henares: Centro de Estudios Cervantinos.

Norton, Frederick John. 1978. A descriptive catalogue of printing in Spain and Portugal 1501-1520. Cambridge: Cambridge University Press.

Petersen, Carl S. \& Vilhelm Andersen. 1924-1934. Illustreret dansk Litteraturhistorie. København: Gyldendal.

Petersen, N.M. 1867. Bidrag til den danske Literaturs Historie. København: Wøldike.

Richter, Anna Katharina \& Jürg Glauser. 2018. "A neglected manuscript. A Danish version of Amadís de Gaula." Danske studier: 30-38.

Richter, Anna Katharina. 2009. Transmissionsgeschichten. Untersuchungen zur dänischen und schwedischen Erzählprosa in der frühen Neuzeit. Tübingen/Basel: Francke.

Schaffert, Henrike. 2015. Der Amadisroman. Serielles Erzählen in der Frühen Neuzeit. Berlin: de Gruyter.

Seelow, Hubert. 1989. Die isländischen Übersetzungen der deutschen Volksbücher: Handschriftenstudien zur Rezeption und Überlieferung ausländischer unterhaltender Literatur in Island in der Zeit zwischen Reformation und Aufklärung. Reykjavík: Stofnun Árna Magnússonar á Íslandi.

Sif Rikhardsdottir. 2012. Medieval Translations and Cultural Discourse. The Movement of Texts in England, France and Scandinavia. Cambridge.

Stangerup, Hakon. 1936. Romanen i Danmark i det attende aarhundrede. København: Levin \& Munksgaard.

Thomas, Henry. 1920. Spanish and Portugese romances of chivalry. Cambridge: Cambridge University Press.

Tristram, Hildegard L. C., ed. 1994. Text und Zeittiefe. Script-Oralia 58. Tübingen: Narr.

Weddige, Hilkert. 1975. Die »Historien vom Amadis auss Frankreich«. Dokumentarische Grundlegung zur Entstehung und Rezeption. Wiesbaden: Steiner.

Wingård, Rikard. 2011. Att sluta från början. Tidigmodern läsning och folkbokens receptionsestetik. Bokenäset: Frondes.

Zumthor, Paul. 1987. La lettre et la voix. De la littérature médiévale. Paris: Edition du Seuil.

Zumthor, Paul. 1972. Essai de poétique médiévale. Paris: Seuil [English translation: Toward a Medieval Poetics, trans. Philip Bennett, Minneapolis: University of Minnesota Press, 1992]. 
